\title{
ELIMINASI LOGAM Cu OLEH SERASAH Avicennia marina DI LINGKUNGAN TAMBAK BANDENG WILAYAH TAPAK TUGUREJO, SEMARANG (Cu Metal Elimination by Avicennia marina Litter Leaf in the Environment of Milkfish Fishpond in Tapak Village, Tugurejo Sub-District, Semarang City)
}

\author{
Nana Kariada Tri Martuti ${ }^{*}$, Budi Widianarko² dan Bambang Yulianto ${ }^{3}$ \\ ${ }^{1}$ Jurusan Biologi, Fakultas Matematika dan Ilmu Pengetahuan Alam, Universitas Negeri Semarang, \\ Kampus Unnes Sekaran, Gunungpati, Semarang, 50229. \\ ${ }^{2}$ Jurusan Teknologi Pangan, Fakultas Teknologi Pertanian, Universitas Katolik Soegijapranata, \\ J1. Pawiyatan Luhur IV/1, Bendan Dhuwur, Semarang 50234. \\ ${ }^{3}$ Jurusan Kelautan, Fakultas Perikanan dan Ilmu Kelautan, Universitas Diponegoro, \\ J1. Prof. H. Soedarto, S.H, Tembalang, Semarang 50275.
}

*Penulis korespondensi. Tel: 081228793345. Email: nana.kariada@yahoo.co.id.

Diterima: 4 Desember 2015

Disetujui: 18 Maret 2016

\begin{abstract}
Abstrak
Serasah mempunyai peran penting dalam transfer logam dari tanaman ke dalam media lingkungan hidupnya. Tujuan penelitian mengkaji tingkat eliminasi logam $\mathrm{Cu}$ melalui proses defoliasi serasah daun Avicennia marina di tambak bandeng. Bahan penelitian terdiri dari air dan sedimen tambak serta serasah daun mangrove dari jenis $A$. marina. Destruksi logam $\mathrm{Cu}$ pada air, sedimen dan serasah menggunakan tefflon bomb extraction, dilanjutkan dengan pengukuran logam $\mathrm{Cu}$ menggunakan AAS. Penelitian dilakukan selama 90 hari pada tambak bandeng wilayah Tapak Semarang, di dalamnya terdapat tumbuhan mangrove $A$. marina. Kadar logam $\mathrm{Cu}$ pada air tambak penelitian antara

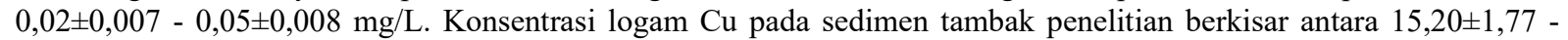
$25,03 \pm 4,77 \mathrm{mg} / \mathrm{kg}$, Faktor Konsentrasi (FK) air dan sedimen tambak penelitian antara 500.52 - 897,70. Serasah daun A. marina mengandung logam $\mathrm{Cu} 2,346 \pm 0,536-5,285 \pm 2,091 \mathrm{mg} / \mathrm{kg}$. Hasil penelitian menunjukkan terdapat kemampuan serasah A. marina dalam mengembalikan logam $\mathrm{Cu}$ ke lingkungan hidupnya. Perbandingan antara serasah dengan air dan sedimen menunjukkan bahwa kemampuan serasah dalam mengembalikan $\mathrm{Cu}$ ke perairan $(46,92$ - 228,72) lebih besar dari pada ke sedimen lingkungan hidupnya (0,094 - 0,318).
\end{abstract}

Kata kunci: Avicennia marina, eliminasi, logam berat, polutan, serasah, tembaga.

\begin{abstract}
Avicennia marina litter plays an important role in the heavy metal transfer from the plant into its environment. It occurs due to its ability in eliminating the metal from its tissue, as its adaptation to metal - polluted environment. The purpose of this research was to examine the elimination level of $\mathrm{Cu}$ through a defoliation process of A. marina into milkfish pond. The objects of the research were water, sediment and A. marina litter. The destruction of Cu in water, sediment and litter was accomplished using tefflon bomb extraction, followed by measurement of Cu using AAS. The study was conducted in milkfish pond in Tapak region at Semarang city for 90 days, in which the A. marina plants grow. The value of copper content in the water pond was between $0.02 \pm 0.007$ to $0.05 \pm 0.008 \mathrm{mg} / \mathrm{L}$. The concentration of $\mathrm{Cu}$ in the sediment ranged from $15.20 \pm 1.77$ to $25.03 \pm 4.77 \mathrm{mg} / \mathrm{kg}$, the concentration factor (CF) of water and waste sediment with water and sediment ranged from 500.52 - 897.70. The content of $\mathrm{Cu}$ in A. marina litter was $2.346 \pm 0.536$ to $5.285 \pm 2.091 \mathrm{mg} / \mathrm{kg}$. The result of the research showed the ability of A. marina litter to reconstruct copper to its environment. The comparison between the ability of A. marina litter to reinstate Cu to water (46.92 to 228.72) is greater than that of the sediment to its environment (0.094-0.318).
\end{abstract}

Keywords: Avicennia marina, copper, elimination, heavy metals, pollutants, litter.

\section{PENDAHULUAN}

Pencemaran logam berat pada wilayah pesisir perlu mendapat perhatian dari berbagai pihak. Keberadaan logam berat dalam perairan yang relatif kecil pun akan sangat mudah diserap dan terakumulasi secara biologis oleh tanaman atau hewan dan akan masuk dalam sistem jaring makanan. Akibat kerusakan pantai dan lahan mangrove di kawasan pesisir menyebabkan penurunan kualitas lingkungan yang akan berpengaruh pada lingkungan tambak di wilayah pesisir. 
Avicennia marina merupakan salah satu jenis mangrove yang termasuk tumbuhan pionir pada wilayah pesisir yang terlindungi, serta mempunyai kemampuan untuk tumbuh pada habitat pasangsurut yang mempunyai salinitas tinggi. Akar A. marina sering membantu mengikat sedimen dan mempercepat proses pembentukan sedimentasi. Jenis mangrove ini bergerombol membentuk suatu kelompok pada habitat tertentu. A. marina mempunyai potensi sebagai fitoremediasi karena kemampuannya hidup pada lingkungan yang tercemar. Akumulasi logam $\mathrm{Cu}$ pada Avicennia lebih tinggi dibandingkan Rhizopora. Hal ini menunjukkan adanya kemampuan zona terdepan hutan mangrove (leading zone) mampu mengakumulasi logam berat lebih banyak dibandingkan zona mangrove di belakangnya (behind zone) (Purwiyanto, 2013). Penelitian Usman dkk. (2013) menyampaikan hasil bahwa $A$. marina mempunyai potensi yang baik dalam mengakumulasi $\mathrm{Cu}$ dari sedimen, hal ini ditunjukkan adanya akumulasi $\mathrm{Cu}$ yang tinggi pada daun dengan Bio Concentration Factor (BCF) dan Translocation Factor (TF) dengan nilai $>1$. Dominasi A. marina serta pengurangan kelimpahan dan keanekaragaman mangrove mengindikasikan adanya tekanan dalam lingkungan (Kulkarni dkk., 2010). Hal ini didasarkan karena kemampuan akar A. marina untuk mengakumulasi $\mathrm{Cu}$ (Mulyadi dkk., 2009). Martuti dan Irsadi (2014) dalam penelitiannya memperoleh hasil bahwa akar pohon api-api (A. marina) dapat mengakumulasi tembaga $(\mathrm{Cu})$.

Serasah merupakan hasil pelapukan mangrove yang berasal dari bagian organ pohon mangrove, berupa daun, bunga, cabang, ranting dan sejumlah bagian pohon lain yang jatuh ke lingkungan hidup mangrove. Untuk dapat dimanfaatkan oleh organisme yang terdapat dalam hutan mangrove, serasah tersebut perlu didekomposisi oleh mikroorganisme menjadi detritus. Detritus inilah yang menjadi sumber makanan bernutrisi tinggi untuk berbagai jenis organisme perairan (khususnya detritifor) yang selanjutnya dapat dimanfaatkan oleh organisme tingkat tinggi (ikan besar, burung pemangsa, ular, atau manusia) dalam jaring-jaring makanan (Zamroni dan Rohyani, 2008; Dewantoro, 2015). Noer (2009) meneliti tentang pemodelan dinamik untuk peluluhan serasah daun mangrove, diperoleh hasil bobot kering serasah yang luruh setiap bulannya sebesar $24,83 \mathrm{~g} / \mathrm{m}^{2}$, dengan laju peluruhan $0,92 /$ bulan. Faktor produksi serasah ini juga merupakan bagian yang penting dalam transfer bahan organik dari vegetasi ke dalam tanah lingkungan hidupnya (Dewantoro, 2015).
Di samping mempunyai peran sebagai penghasil detritus yang bermanfaat bagi organisme lain, serasah daun dari tumbuhan mangrove juga mempunyai kemampuan mengembalikan logam berat ke dalam lingkungan. Saenger dan McConchie (2004) mengatakan bahwa serasah daun mangrove yang tersebar ke perairan dapat melepaskan kembali logam ke lingkungannya, meskipun kemampuan melepaskan logamnya relatif kecil. Penelitian MacFarlane dan Burchett (2000) menyatakan bahwa dalam pengamatan A. marina selama satu bulan, terjadi pelepasan logam oleh daun tua, secara signifikan konsentrasi $\mathrm{Zn}$ dan $\mathrm{Cu}$ lebih tinggi dibandingkan tumbuhan kontrol. Hal ini menunjukkan adanya ekskresi kedua logam tersebut pada kelenjar trikoma. Epidermis akar menjadi penghalang utama hanya untuk pengangkutan $\mathrm{Pb}$ saja. Endodermalcasparian berperan sebagai penghalang terhadap pergerakan $\operatorname{logam} \mathrm{Cu}, \mathrm{Pb}$ dan $\mathrm{Zn}$, yaitu terakumulasi dalam jaringan daun, selanjutnya $\mathrm{Zn}$ dan $\mathrm{Cu}$ tersebut akan dikeluarkan melalui kelenjar garam pada permukaan bawah daun.

Seiring pertambahan waktu, peningkatan aktivitas manusia, dan perluasan tata guna lahan mangrove menjadi tambak dan permukiman, akan menimbulkan pasokan logam $\mathrm{Cu}$ yang berbeda. Pada akhirnya dapat merubah konsentrasi logam $\mathrm{Cu}$ yang diserap oleh akar dan daun $A$. marina yang hidup di lingkungan perairan pesisir.

Berdasarkan latar belakang tersebut, maka perlu dilakukan kajian mengenai tingkat eliminasi logam $\mathrm{Cu}$ melalui proses defoliasi serasah daun $A$. marina di tambak bandeng, sehingga dapat diketahui kemampuan serasah dalam mengembalikan logam ke lingkungan tambak tersebut. Tujuan penelitian adalah untuk mengkaji tingkat eliminasi logam $\mathrm{Cu}$ melalui proses defoliasi serasah daun A. marina di tambak bandeng wilayah Tapak Semarang.

\section{METODE PENELITIAN}

\section{Waktu dan Lokasi}

Penelitian dilakukan pada bulan Januari sampai Juni 2015. Penelitian dilakukan pada tambak bandeng wilayah Tapak Tugurejo, Kecamatan Tugu, Kota Semarang. Lokasi penelitian berada pada koordinat $110^{\circ} 17^{\prime} 15^{\prime \prime}$ BT $110^{\circ} 22^{\prime} 4$ " BT dan 6056'13" LS - 6059'14” LS (Gambar 1). Wilayah Tapak merupakan satu kawasan pesisir Kota Semarang yang terdapat tambak dengan ekosistem mangrove. Analisis logam $\mathrm{Cu}$ dilakukan di Laboratorium Teknologi Pangan Fakultas Teknologi Pertanian Universitas Katolik Soegijapranata Semarang. 


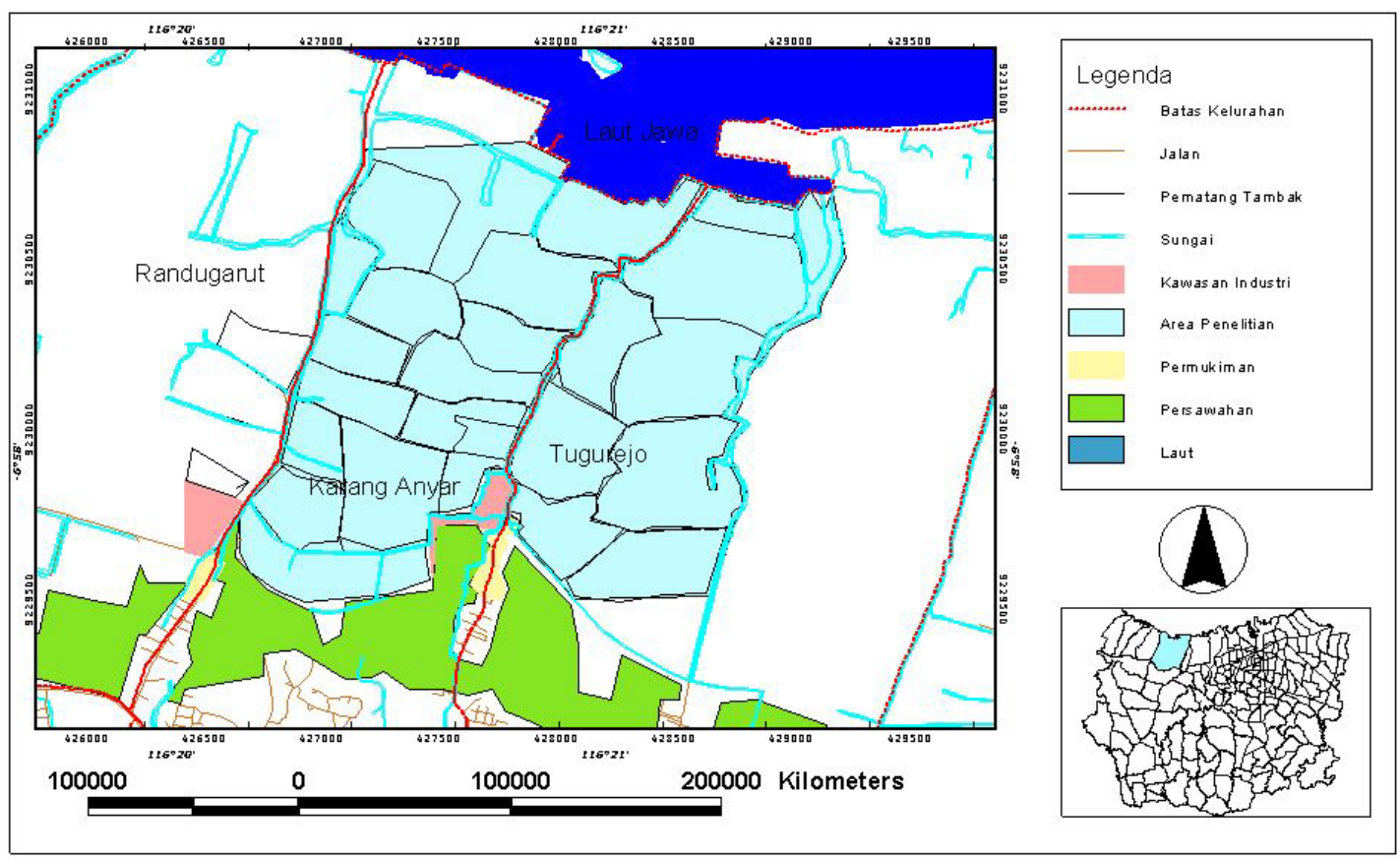

Gambar 1. Peta lokasi penelitian di Wilayah Tapak Tugurejo Semarang

\section{Prosedur}

Bahan yang digunakan pada penelitian terdiri dari air dan sedimen tambak serta serasah daun mangrove dari jenis Avicennia marina. Pengambilan sampel dilakukan selama 3 bulan dengan selang waktu pengambilan sampel masingmasing 15 hari, dengan masing-masing sampel diambil 8 kali ulangan.

Pengambilan sampel dilakukan secara random sampling, dengan memperhatikan keberadaan dan umur A. marina yang dapat mewakili kondisi tambak pada lokasi yang akan diteliti. Sampel air diperoleh dengan cara mengambil air tambak sebanyak $50 \mathrm{~mL}$, sedimen dan serasah daun sebanyak $50 \mathrm{~g}$ untuk dianalisis $\operatorname{logam} \mathrm{Cu}$ di laboratorium. Serasah diambil menggunakan jaring yang dipasang di bawah tumbuhan A. marina pada tambak yang sudah ditentukan. Destruksi logam $\mathrm{Cu}$ pada air, sedimen dan serasah dilakukan menggunakan tefflon bomb extraction yang dilanjutkan dengan pembacaan logam dengan menggunakan AAS.

Konsentrasi logam pada air dan sedimen tambak diukur dengan Faktor Konsentrasi (FK). Kemampuan serasah dalam mengembalikan logam ke lingkungan perairan dihitung dengan perbandingan antara konsentrasi logam $\mathrm{Cu}$ dalam serasah dengan konsentrasi logam dalam air dan sedimen. Data yang terkumpul dianalisis secara deskriptif untuk mengetahui kemampuan serasah dalam pengembalian logam $\mathrm{Cu}$ pada perairan tambak selama 3 bulan waktu penelitian.

\section{HASIL DAN PEMBAHASAN}

Hasil laboratorium terhadap konsentrasi logam $\mathrm{Cu}$ di perairan tambak selama 90 hari penelitian, menunjukkan bahwa rata-rata konsentrasi logam $\mathrm{Cu}$ pada air berkisar antara 0,02 $\pm 0,007-0,05 \pm 0,008$ $\mathrm{mg} / \mathrm{L}$ (Tabel 1). Konsentrasi terbesar pada hari pertama $0,05 \mathrm{mg} / \mathrm{L}$, sedangkan pada penelitian hari ke 15 sampai ke 90 diperoleh hasil yang relatif sama dengan nilai berkisar antara $0,02-0,03 \mathrm{mg} / \mathrm{L}$.

Hasil laboratorium tersebut menunjukkan bahwa kadar logam $\mathrm{Cu}$ pada air tambak wilayah Tapak $(0,02-0,05 \mathrm{mg} / \mathrm{L})$, berada di atas ambang batas yang telah ditentukan Pemerintah. Sesuai dengan Keputusan Menteri Lingkungan Hidup No 51 Tahun 2004 tentang Baku Mutu Air Laut, kadar $\mathrm{Cu}$ untuk biota air laut $0,008 \mathrm{mg} / \mathrm{L}$. Hasil ini lebih tinggi dari hasil penelitian Martuti dan Irsadi (2014) yang menyampaikan kadar logam $\mathrm{Cu}$ dalam perairan tambak wilayah Tapak antara 0,001-0,007 dan 0,005 - 0,037 mg/L pada Sungai Tapak.

Tabel 1. Hasil rataan konsentrasi logam $\mathrm{Cu}$ pada air dan sedimen tambak beserta standar deviasi

\begin{tabular}{ccc}
\hline Hari ke & \multicolumn{2}{c}{ Rataan logam Cu pada air dan sedimen } \\
\cline { 2 - 3 } & Air $(\mathrm{mg} / \mathrm{L})$ & Sedimen $(\mathrm{mg} / \mathrm{kg})$ \\
\hline 1 & $0,05 \pm 0,008$ & $25,03 \pm 4,77$ \\
15 & $0,03 \pm 0,005$ & $19,65 \pm 2,23$ \\
30 & $0,03 \pm 0,005$ & $18,00 \pm 4,80$ \\
45 & $0,02 \pm 0,007$ & $20,65 \pm 3,52$ \\
60 & $0,03 \pm 0,007$ & $17,20 \pm 3,97$ \\
75 & $0,02 \pm 0,005$ & $16,09 \pm 3,41$ \\
90 & $0,03 \pm 0,004$ & $15,20 \pm 1,77$ \\
\hline
\end{tabular}

Sumber: Data primer (2015). 
Tabel 2. FK rataan konsentrasi logam $\mathrm{Cu}$ pada air dan sedimen tambak penelitian.

\begin{tabular}{lccccccc}
\hline \multirow{2}{*}{ Parameter } & \multicolumn{7}{c}{ Pengamatan hari ke- } \\
\cline { 2 - 8 } & 1 & 15 & 30 & 45 & 60 & 75 & 90 \\
\hline Cu di Air (mg/L) & 0,05 & 0,034 & 0,025 & 0,023 & 0,033 & 0,024 & 0,029 \\
Sedimen (mg/kg) & 25,026 & 19,65 & 18,001 & 20,647 & 17,20 & 16,090 & 15,203 \\
FK & 500,52 & 577,94 & 720,04 & 897,70 & 521,21 & 670.42 & 524,24 \\
\hline
\end{tabular}

Sumber: Data primer (2015).

Logam berat merupakan bahan pencemar yang berbahaya karena bersifat toksik. Jika terdapat dalam jumlah yang besar dapat mempengaruhi aspek ekologis maupun aspek biologis perairan. Logam $\mathrm{Cu}$ yang terdapat dalam lingkungan perairan dapat terakumulasi dalam organisme yang hidup di perairan tersebut. Sebagaimana yang disampaikan Defew dkk. (2004), logam berat yang masuk ke dalam lingkungan perairan akan mengalami pengendapan, pengenceran dan dispersi, kemudian diserap oleh organisme yang hidup di perairan tersebut.

Rata-rata konsentrasi logam $\mathrm{Cu}$ pada sedimen tambak penelitian berkisar antara 15,20 $\pm 1,77$ $25,03 \pm 4,77 \mathrm{mg} / \mathrm{kg}$. Konsentrasi terbesar diperoleh pada hari pertama sebesar $33,321 \mathrm{mg} / \mathrm{kg}$, dan konsentrasi terendah pada hari ke 60 sebesar 11,14 $\mathrm{mg} / \mathrm{kg}$. Keberadaan logam $\mathrm{Cu}$ pada sedimen ini dimungkinkan karena faktor kemampuan sedimen dalam mengakumulasi logam dari lingkungannya. Keberadaan logam pada sedimen sangat tergantung pada baik buruknya kondisi perairan tersebut. Keberadaan logam $\mathrm{Cu}$ pada sedimen hal ini dimungkinkan karena adanya kemampuan sedimen dalam mengakumulasi logam dari lingkungannya. Purwiyanto (2013) dalam penelitiannya menyampaikan, logam $\mathrm{Cu}$ merupakan logam berat yang cenderung mudah untuk terendapkan dalam sedimen, sehingga akumulasi logam $\mathrm{Cu}$ pada sedimen akan lebih tinggi dibandingkan akumulasi pada kolom air.

Perhitungan FK antara air dan sedimen tambak pada penelitian disajikan pada Tabel 2. Data yang diperoleh menunjukkan nilai antara 500,52 897,70 . Hasil tersebut menggambarkan bahwa kadar logam dalam sedimen tambak secara signifikan lebih tinggi dibandingkan kadar logam $\mathrm{Cu}$ pada air tambak. Faktor konsentrasi ini menunjukkan adanya kemampuan sedimen dalam mengakumulasi logam $\mathrm{Cu}$ dari perairan.

Kuantitas konsentrasi logam pada air dan sedimen tambak menunjukkan adanya pencemaran logam $\mathrm{Cu}$ pada media tempat hidup ikan di tambak wilayah Tapak. Pencemaran logam $\mathrm{Cu}$ di Tapak ini dimungkinkan karena wilayah Tapak merupakan muara dari Sungai Tapak. Wilayah Tapak merupakan wilayah yang didominasi permukiman, pertanian dan industri yang menyebabkan wilayah Tapak mempunyai potensi resiko tercemar bahanbahan berbahaya, termasuk logam. Keberadaan berbagai aktivitas manusia seperti industrialisasi dan urbanisasi memberikan dampak jangka panjang terhadap lingkungan, termasuk kontaminasi logam berat pada ekosistem mangrove (Davari dkk., 2012). Marjanto (2005) dalam penelitiannya menyampaikan, perkembangan industri di hulu Kali Tapak juga telah menyebabkan peningkatan jumlah atau volume limbah cair serta penurunan kualitas air sungai, yang menyebabkan badan air kali yang semula hanya bersumber dari mata air telah bercampur dengan limbah cair dari kegiatan industri. Air yang telah tercampur limbah industri ini menyebabkan permasalahan bagi para petani di Tapak dalam memenuhi kebutuhan pengairan sawah dan pertambakan yang berpengaruh terhadap produktivitasnya.

Hasil uji laboratorium terhadap serasah daun A. marina (Tabel 3) menunjukkan adanya konsentrasi logam $\mathrm{Cu}$ pada serasah antara $2,346 \pm 0,536-5,285 \pm 2,091 \mathrm{mg} / \mathrm{kg}$. Hasil tersebut menunjukkan konsentrasi logam $\mathrm{Cu}$ serasah yang lebih tinggi dari konsentrasi logam $\mathrm{Cu}$ dalam air tambak yang mempunyai konsentrasi antara $0,02 \pm 0,007$ - 0,05 $\pm 0,008 \mathrm{mg} / \mathrm{L}$. Berdasarkan perhitungan perbandingan antara serasah dan air (Tabel 4), diperoleh hasil nilai antara 46,92 228,72 selama jangka waktu penelitian. Nilai perbandingan ini menunjukkan adanya akumulasi logam $\mathrm{Cu}$ pada serasah yang lebih tinggi dari air. Hal ini dimungkinkan karena serasah merupakan pengguguran daun tua dari tanaman A. marina. Daun merupakan bagian tanaman yang mampu mengakumulasi logam melalui proses translokasi dari akar dan batang tanaman.

Konsentrasi logam $\mathrm{Cu}$ yang tinggi pada serasah, dikarenakan adanya proses adaptasi tanaman dalam mempertahankan diri terhadap lingkungan yang tercemar dengan cara mengekresikan logam $\mathrm{Cu}$ melalui daun, yang

Tabel 3. Hasil rataan konsentrasi logam $\mathrm{Cu}$ pada serasah A. marina beserta standar deviasi.

\begin{tabular}{cc}
\hline Pengamatan hari ke & Konsentrasi $\mathrm{Cu}(\mathrm{mg} / \mathrm{kg})$ \\
\hline 1 & $2,346 \pm 0,536$ \\
15 & $2,499 \pm 1,091$ \\
45 & $5,718 \pm 1,737$ \\
60 & $4,655 \pm 2,040$ \\
75 & $5,285 \pm 2,091$ \\
90 & $4,836 \pm 0,573$ \\
\hline
\end{tabular}

Sumber: Data primer (2015). 
Tabel 4. Nilai perbandingan antara air dan serasah A. marina pada tambak bandeng.

\begin{tabular}{lrlrrrrr}
\hline Parameter & \multicolumn{7}{c}{ Pengamatan hari ke } \\
\cline { 2 - 8 } & \multicolumn{1}{c}{15} & \multicolumn{1}{c}{30} & \multicolumn{1}{c}{45} & \multicolumn{1}{c}{60} & \multicolumn{1}{c}{0} & \multicolumn{1}{c}{90} \\
\hline Cu di air $(\mathrm{mg} / \mathrm{L})$ & 0,050 & 0,034 & 0,025 & 0,023 & 0,033 & 0,024 & 0,029 \\
Cu di serasah (mg/kg) & 2,346 & 2,499 & 5,718 & 4,655 & 5,285 & 4,836 & 4,009 \\
Nilai perbandingan & 46,92 & 73,50 & 228,72 & 202,39 & 160,15 & 201,50 & 138,24 \\
\hline
\end{tabular}

Sumber: Data primer (2015).

Tabel 5. Rataan konsentrasi logam $\mathrm{Cu}$ dan nilai perbandingan antara sedimen dan serasah daun $A$. marina pada tambak bandeng.

\begin{tabular}{lrrrrrrr}
\hline Parameter & \multicolumn{7}{c}{ Pengamatan hari ke } \\
\cline { 2 - 7 } & 1 & 15 & 30 & 45 & 60 & 75 & 90 \\
\hline Cu di sedimen $(\mathrm{mg} / \mathrm{kg})$ & 25,026 & 19,65 & 18,001 & 20,647 & 17,2 & 16,09 & 15,203 \\
$\mathrm{Cu}$ di serasah $(\mathrm{mg} / \mathrm{kg})$ & 2,346 & 2,499 & 5,718 & 4,655 & 5,285 & 4,836 & 4,009 \\
Nilai perbandingan & 0,094 & 0,127 & 0,318 & 0,225 & 0,307 & 0,301 & 0,264 \\
\hline
\end{tabular}

Sumber: Data primer (2015).

selanjutnya logam dilepaskan melalui pengguguran daun tua (serasah). Sebagaimana yang disampaikan Barutu dkk. (2014), jumlah akumulasi pada daun biasanya merupakan usaha lokalisasi yang dilakukan oleh tumbuhan yaitu mengumpulkan dalam satu organ baik intraseluler maupun ekstraseluler yang bisa juga terjadi pada daun. Proses ini merupakan salah satu bentuk ekskresi tumbuhan secara aktif melalui kelenjar pada tajuk, atau secara pasif dengan akumulasi pada daun dengan ditandai pelepasan daun tua. Hasil penelitian sesuai dengan penelitian Amin (2001) yang menyampaikan bahwa tumbuhan A. marina mampu mengakumulasi logam berat $\mathrm{Cu}$ di bagian daun, baik daun muda maupun daun tua.

Ekskresi merupakan salah satu bentuk mekanisme tumbuhan dalam menghadapi konsentrasi toksik di lingkungannya. Ekskresi secara aktif dilakukan melalui kelenjar pada tajuk dan secara pasif melalui akumulasi pada daun-daun tua yang diikuti dengan absisi daun (Fitter dan Hay, 1992). Sebagaimana disampaikan oleh MacFarlane dan Burchett (2000), adanya logam $\mathrm{Zn}$ dan $\mathrm{Cu}$ yang ditemukan dalam jaringan tumbuhan akan dikeluarkan melalui kelenjar garam pada permukaan bawah daun. Kondisi ini hampir sama ketika tumbuhan berada pada kondisi kadar garam yang tinggi, mekanisme yang digunakan tumbuhan A. marina untuk bertahan hidup dengan melepaskan garam dengan pengguguran daun. Zamroni dan Rohyani (2008), menyampaikan tingginya kontribusi daun terhadap produktivitas serasah yang dihasilkan terkait dengan salah satu bentuk adaptasi tumbuhan mangrove untuk mengurangi kehilangan air agar dapat bertahan hidup pada kondisi kadar garam tinggi.

Terjadinya proses ekresi logam dari jaringan tanaman melalui serasah daun ini dapat mengembalikan logam tersebut ke lingkungan hidupnya. Pengembalian logam ke lingkungan melalui serasah merupakan mekanisme adaptasi tumbuhan dalam kondisi lingkungan yang ekstrim. Saenger dan McConchie (2004) dalam penelitiannya menyampaikan, serasah daun mangrove dapat mengembalikan logam berat ke dalam lingkungannya dalam bentuk bioavailable, tetapi jumlah logam yang dikeluarkan relatif sedikit. Untuk serasah daun biasanya lebih cepat tersebar, yang menyebabkan pelepasan logam dari serasah daun ke lingkungan relatif rendah. Produktivitas biomassa dan serasah dari hutan mangrove bervariasi dengan umur mangrove, spesies dominan, dan lokalitas (Qiu dkk., 2011).

Perhitungan nilai perbandingan antara rataan konsentrasi logam $\mathrm{Cu}$ pada sedimen dengan ratarata konsentrasi logam $\mathrm{Cu}$ dalan serasah daun mangrove, diperoleh hasil nilai antara 0,094 - 0,318 (Tabel 5). Hasil ini menunjukkan konsentrasi logam $\mathrm{Cu}$ pada sedimen lingkungan hidup jauh lebih tinggi dari konsentrasi serasah A. marina. Hasil ini dimungkinkan karena sedimen merupakan bagian yang mudah mengakumulasi bahan pencemar. Sedimen merupakan media hidup yang dapat menjerap logam dikerenakan bentuk teksturnya yang halus dan sifatnya menetap. Hasil penelitian sesuai dengan pernyataan Wen-Jiao dkk. (1997) yang menyampaikan, konsentrasi logam berat $(\mathrm{Cu}$, $\mathrm{Pb}, \mathrm{Zn}, \mathrm{Cd})$ dalam sedimen jauh lebih tinggi dari pada dalam tumbuhan (akar, ranting, daun dan bunga) dan serasah daun yang jatuh ke perairan.

Abohassan (2013), dalam penelitiannya menyampaikan, sedimen pada ekosistem mangrove mengandung logam berat yang paling tinggi, diikuti oleh tanaman mangrove (akar, batang dan daun). Selanjutnya kurang dari 3,5\% logam berat tersebut akan dikembalikan oleh serasah ke sedimen lingkungan hidupnya. Keberadaan logam tembaga (Cu) pada serasah daun tidak memperlihatkan adanya hubungan yang signifikan dengan $\mathrm{Cu}$ pada sedimen sepanjang waktu pengambilan sampel. 
Konsentrasi $\mathrm{Cu}$ dalam serasah daun mangrove pada semua lokasi penelitian menunjukkan hasil 0,09 kali tingkat $\mathrm{Cu}$ sedimen (MacFarlane dkk., 2003)

\section{KESIMPULAN}

Dari penelitian yang telah dilakukan, dapat disimpulkan adanya kemampuan serasah $A$. marina dalam mengembalikan logam $\mathrm{Cu}$ ke lingkungan hidupnya. Berdasarkan hasil nilai perbandingan antara serasah dengan air dan sedimen selama 3 bulan waktu penelitian, menunjukkan hasil bahwa kemampuan serasah dalam mengembalikan $\mathrm{Cu}$ ke perairan $(46,92$ - 228,72) lebih besar dari pada ke sedimen lingkungan hidupnya $(0,094-0,318)$.

\section{DAFTAR PUSTAKA}

Abohassan, R.A., 2013. Heavy Metal Pollution in Avicennia marina Mangrove Systems on the Red Sea Coast of Saudi Arabia. Met., Env. \& Arid. Land. Agric. Sci., 24(1):35-53.

Amin, B., 2001. Akumulasi dan Distribusi Logam Berat $\mathrm{Pb}$ dan $\mathrm{Cu}$ pada Mangrove (Avicennia marina) di Perairan Pantai Dumai, Riau. Jurnal Natur Indonesia, 4(1):80-86.

Barutu, H.L., Amin, B., dan Efriyeldi, 2014. Konsentrasi Logam Berat $\mathrm{Pb}, \mathrm{Cu}$, dan $\mathrm{Zn}$ Pada Avicennia marina di Pesisir Kota Batam Provinsi Kepulauan Riau. Website: http://download.portalgaruda.org/article.php?a rticle.diakses 25 Agustus 2015.

Davari, A., Danehkar, A., Khorasani, N., dan Javanshir., A., 2012. Identification of Heavy Metals Contamination at Bushehr Mangroves, Journal of Environmental Studies, 38(3):7 - 9.

Defew, L.H., James M.M., dan Hector, M.G., 2004. An Assessment of Metal Contamination in Mangrove Sediments and Leaves from Punta Mala Bay, Pacific Panama. Marine Pollution Bulletin, 50:547-552.

Dewantoro, A., 2015. Sistem Dekomposisi Serasah Hutan Mangrove. Website: http://tgc.lk.ipb. ac.id/2015/05/18/sistem-dekomposisi-serasahhutan-mangrove/. Diakses 24 Agustus 2015.

Fitter, A.H., dan Hay, R.K.M., 1992. Fisiologi Lingkungan Tanaman. Gadjah Mada University Press. Yogyakarta.

Kulkarni V.A., Tanaji, G.J., Mhalsekar, N.M., dan Naik, A.N., 2010. Biological and Environmental Characteristics of Mangrove Habitats from Manori Creek, West Coast, India. Environ. Monit. Assess., 168:587-596.

MacFarlane, G.R, dan Burchett, M.D., 2000. Cellular Distribution of Copper, Lead and Zinc in the Grey Mangrove, Avicennia marina (Forsk.) Vierh. Aquatic Botany, 68:45-59.

MacFarlane, G.R., Pulkownik A., dan Burchett, M.D., 2003. Accumulation and Distribution of Heavy Metals in the Grey Mangrove, Avicennia marina (Forsk.) Vierh.: Biological Indication Potential. Environmental Pollution, 123:139-151.

Marjanto, W.D., 2005. Evaluasi Penyelesaian Sengketa Lingkungan Hidup. Program Pasca Sarjana, Universitas Diponegoro. Semarang.

Martuti, N.K.T., dan Irsadi, A., 2014. Peran Mangrove Sebagai Biofilter Pencemaran Air Wilayah Tambak Bandeng Tapak, Semarang. J. Manusia dan Lingkungan, 21(2):188-194

Mulyadi, E., Laksmono, R., dan Aprianti, D., 2009. Fungsi Mangrove Sebagai Pengendali Pencemar Logam Berat. J. Ilmiah Teknik Lingkungan, 1:33-39.

Noer, A.H., 2009. Model Dinamik Rantai Makanan pada Ekosistem Mangrove di Laguna Tasilaha. Media Litbang Sulteng, 2(2):110120.

Purwiyanto, A.I.S., 2013. Daya Serap Akar dan Daun Mangrove Terhadap Logam Tembaga $(\mathrm{Cu})$ di Tanjung Api-Api, Sumatera Selatan, Maspari Journal, 5(1):1-5.

Qiu, Y.W., Yu, K.F., Zhang, G., dan Wang, W.X., 2011. Accumulation and Partitioning of Seven Trace Metals in Mangroves and Sediment Cores from Three Estuarine Wetlands of Hainan Island, China. Journal of Hazardous Materials, 190:631-638.

Saenger, P., dan McConchie, D., 2004. Heavy Metals in Mangroves: Methodology, Monitoring and Management, Envi. Forest Bulletin, 4:52-62.

Usman, A.R.A., Alkredaa, R.S., dan Al-Wabel, M.I., 2013. Heavy Metal Contamination in Sediments and Mangroves from the Coast of Red Sea: Avicennia marina as Potential Metal Bioaccumulator. Ecotoxicology and Environmental Safety, 97:263-270.

Wen-jiao, Z., Xiao-yong, C and Peng, L., 1997. Accumulation and biological cycling of heavy metal elements in Rhizophora stylosa mangroves in Yingluo Bay, China. Marine Ecology Progress Series. 159:293-301.

Zamroni, Y., dan Rohyani, I.S., 2008. Produksi Serasah Hutan Mangrove di Perairan Pantai Teluk Sepi, Lombok Barat. Biodiversitas, 9(4):284-287. 